\title{
PENGARUH SUHU DAN WAKTU PENGEPRESAN TERHADAP MUTU ORGANOLEPTIK BUBUK KAKAO SEBAGAI BAHAN BAKU MINUMAN COKLAT
}

\author{
Effect of Extraction Time and Temperature on The Organoleptic Quality of Cocoa Powder \\ 1 for Chocolate Drink Raw Material \\ Satria Bhirawa Anoraga1, Sri Wijanarti', Iman Sabarisman ${ }^{1}$ \\ ${ }^{1}$ Program Studi Agroindustri, Departemen Teknologi Hayati dan Veteriner, Sekolah Vokasi \\ Universitas Gadjah Mada, Jl. Yacaranda, Sekip, Yogyakarta \\ Email: satriabhirawa@ugm.ac.id
}

\begin{abstract}
Chocolate drink is a favourite product which has many benefit for human health. Main ingredient of chocolate drink is cocoa powder. Pressing process is an important step to produce cocoa powder. It extract cocoa butter from cocoa liquor, leaving a solid mass called bungkil (cocoa presscake) which is broken and milled to be cocoa powder. The aim of the research was to investigate the effect of extraction time and temperature on organoleptic quality of cocoa powder. The study was conducted at Cocoa Processing Incubation Laboratory, Agroindustry Program, Vocational College, Universitas Gadjah Mada in JuniJuli 2018. The samples were fermented cocoa beans obtained from Banjaroya, Kulonprogo. First, cocoa beans were roasted and liquored. Then, $200 \mathrm{~g}$ cocoa liquor were extracted for 20, 30 and 45 minutes at 70, 100 and $110^{\circ} \mathrm{C}$. The parameters observed were organoleptic attributes such as color, flavour, taste, and acidity. The data obtained were analyzed using ANOVA. The results showed that effect of extraction time and temperature were significant $(p<0,5)$ for flavour, color, and acidity in scoring test, and also aroma in hedonic test.
\end{abstract}

\begin{abstract}
ABSTRAK
Minuman coklat merupakan produk yang disukai banyak orang dan memiliki dampak positif bagi kesehatan. Bahan baku minuman coklat yang paling dominan adalah bubuk kakao. Salah satu proses penting untuk menghasilkan bubuk kakao adalah pengepresan. Pengepresan merupakan proses memisahkan lemak dari nib kakao yang telah dipasta. Produk hasil pengepresan berupa bungkil kakao yang kemudian dihaluskan untuk menjadi bubuk kakao. Penelitian ini bertujuan untuk mengetahui pengaruh suhu dan waktu pengepresan terhadap mutu organoleptik bubuk kakao. Pengamatan dilakukan selama bulan Juni-Juli di Laboratorium Inkubasi Pengolahan Kakao, Prodi Agroindustri, Universitas Gadjah Mada. Sampel yang digunakan adalah biji kakao terfermentasi dari Desa KakaoBanjaroya, Kulonprogo. Pada percobaan ini, sampel biji kakao yang telah disangrai dibuat pasta terlebih dahulu. Kemudian pasta kakao sebanyak $200 \mathrm{~g}$ dipres selama 20, 30 dan 45 menit menggunakan variasi suhu 70,100 dan $110^{\circ} \mathrm{C}$. Parameter yang diamati adalah sifat organoleptik seperti aroma, rasa, warna dan keasaman, yang diuji menggunakan uji kesukaan dan uji skoring. Hasil penelitian menunjukkan bahwa suhu dan lama pengepresan berpengaruh signifikan $(p<0,5)$ terhadap rasa, warna dan keasaman untuk uji skoring, dan aroma untuk uji hedonik.
\end{abstract}

Kata kunci: bubuk kakao, pengepresan, lemak, suhu 


\section{PENDAHULUAN}

\section{Latar Belakang}

Coklat merupakan produk pangan yang digemari banyak orang. Pada umumnya cokelat disajikan dalam bentuk permen, makanan ringan, kue maupun hidangan penutup yang memiliki nutrisi tinggi (Rocha et al., 2017). Beberapa waktu akhir ini, banyak orang suka mengkonsumsi coklat dalam bentuk minuman, dimana bahan baku utamanya adalah bubuk kakao. Minuman coklat dirasa nikmat dan baik untuk kesehatan, karena dengan mengkonsumsi minuman bubuk kakao setiap hari selama 25 hari dapat berpengaruh nyata dalam meningkatkan kapasitas antioksidan sel limfosit manusia (Erniati, dkk., 2012). Selain untuk minuman, bubuk kakao juga banyak digunakan untuk berbagai macam industri pangan (Y. Li et al., 2012). Seperti yang dilakukan Hadi dan Siratunnisak (2016) yang memberi tambahan bubuk kakao pada minuman instan bekatul. Sebagai bahan baku yang dominan pada minuman coklat, kualitas bubuk kakao harus dijaga dan disesuaikan dengan keinginan konsumen. Salah satu proses pengolahan bubuk kakao yang penting adalah proses pengepresan.

Beberapa tahapan pascapanen kakao dipengaruhi oleh faktor suhu dalam proses pengolahannya. Pada pengolahan sekunder kakao, tahapan yang melibatkan suhu dalam prosesnya adalah penyangraian, pengepresan dan penghalusan atau koncing. Suhu merupakan faktor utama penyebab munculnya pewarnaan cokelat pada biji kakao saat disangrai. Terbentuknya pigmen warna cokelat yang dinamis pada penyangraian dipengaruhi oleh tingkat suhu penyangraian (Nazaruddin, 2006). Pada proses penghalusan, suhu koncing yang terlalu rendah dapat menyebabkan bubuk kakao kembali menjadi bentuk bongkahan. Sehingga pada proses penghalusan perlu dilakukan kontrol suhu agar tidak dibawah $34^{\circ} \mathrm{C}$, sehingga diperoleh bubuk kakao yang stabil bentuk warna dan sifat-sifatnya
(Adeyeye, 2010). Sri Mulato (2004) juga mengatakan, bahwa suhu proses untuk pproduk cokelat susu sebaiknya tidak lebih dari $70^{\circ} \mathrm{C}$, karena pasta cokelat yang masih memerlukan tambahan komposisi lemak akan cenderung beraroma cooked flavour atau memiliki aroma yang terlalu matang.

Pengempaan merupakan proses untuk memisahkan lemak kakao dari pasta atau nib yang telah dihaluskan. Jumlah lemak yang dapat dipisahkan dipengaruhi oleh lama pengempaan yang dilakukan, tekanan yang digunakan, dan ukuran partikel pasta yang diekstrak (Setiawan, 2007).

Aroma dan cita rasa coklat dipengaruhi oleh beberapa komponen kimia penyusun biji kakao. Komponen kimia tersebut berupa senyawa volatil (aroma) seperti aldehid, keton dan beberapa senyawa karbonil, sedangkan beberapa senyawa lain seperti polifenoil, teobromin dan asam-asam organik berperan sebagai pembentuk cita rasa (Wahyudi, 1988). Adanya panas saat proses penyangraian membuat senyawasenyawa calon pembentuk cita rasa bereaksi satu sama lain melalui reaksi Maillard menghasilkan komponenkomponen mudah menguap dan beraroma khas cokelat (Jinap, 1998). Perubahan kimiawi seperti warna kecokelatan, tekstur, senyawa volatil, keasaman dan kandungan lemak tergantung pada suhu yang digunakan selama proses pengolahan (Rocha et al., 2017).

Beberapa pengamatan terkait pengaruh pengepresan terhadap kualitas bubuk kakao telah banyak dilakukan. Seperti yang dilakukan Indarti (2007) tentang pengaruh pemanasan terhadap perolehan lemak kakao selama pengepresan. Junaidi (2008) meneliti pengaruh perlakuan suhu ekstraksi terhadap karakteristik mutu lemak kakao, dengan variasi suhu berkisar $40-90^{\circ} \mathrm{C}$. Chatib (2015) melakukan pengamatan terhadap alat pengepres bubuk kakao untuk porduksi lemak kakao berkualitas beserta analisis hasilnya. Namun sejauh ini 
belum ada yang mengamati lebih dalam terkait pengaruh suhu pengepresan terhadap mutu organoleptik bubuk kakao.

Penelitian ini perlu dilakukan mengingat bahwa Pemerintah Republik Indonesia melalui Kementerian Perindustrian telah mewajibkan pemberlakuan ketentuan Standar Nasional Indonesia (SNI) terhadap produk kakao bubuk sejak tanggal 4 November 2009.

\section{Tujuan}

Penelitian ini bertujuan untuk mengetahui pengaruh suhu dan lama pengepresan terhadap mutu organoleptik bubuk kakao yang dihasilkan. Bubuk kakao tersebut akan dianalisis aroma, rasa, warna dan keasaman kemudian dibandingkan dengan standar yang berlaku.

\section{METODE PENELITIAN}

\section{Alat dan Bahan}

Bahan yang digunakan pada penelitian ini adalah biji kakao terfermentasi dari Desa Kakao Banjaroya, Kulonprogo. Biji kakao disangrai selama 10-15 menit pada suhu $100^{\circ} \mathrm{C}$ hingga berubah warna dan muncul aroma cokelat. Setelah keluar dari penyangrai dan tidak terlalu panas, biji kakao dikupas kulit arinya untuk memperoleh nib kakao. Nib tersebut dipasta dan selanjutnya dilakukan pengepresan.

Alat yang digunakan antara lain alat penyangrai, alat pemasta, alat pengepres tipe mekanis, timbangan analitik, oven, dan peralatan pendukung lainnya seperti cawan, nampan, dan gelas ukur. Penelitian dilakukan pada bulan Juni-Juli 2018 di Pusat Inkubasi Pengolahan Kakao, Program Studi Agroindustri, Sekolah Vokasi Universitas Gadjah Mada.

\section{Metode}

Pasta kakao dimasukkan kedalam kain saring dengan dua varian sebanyak $200 \mathrm{~g}$, dan dipres menggunakan alat pengepres mekanis. Proses pengepresan menggunakan variasi suhu 70, 100 dan $110^{\circ} \mathrm{C}$, dengan variasi waktu lama pengepresan selama 20, 30, 45 menit. Bungkil kakao dari pengepresan dihaluskan, kemudian dilakukan uji skoring dan uji kesukaan (hedonik) terhadap organoleptik bubuk kakao, yang terdiri dari rasa, aroma, warna dan keasaman.

\section{Analisis Data}

Bubuk kakao dengan tiga variasi waktu dan suhu pengepresan diuji secara sensori (uji skoring dan uji kesukaan/hedonik) untuk mengetahui tingkat penerimaan berdasarkan penilaian dan kesukaan panelis terhadap mutu organoleptik bubuk kakao. Uji kesukaan dan skoring ini dilakukan oleh 25 orang panelis tidak terlatih. Parameter yang dinilai dalam uji ini meliputi warna, aroma, rasa, dan keasaman. Pertama, dilakukan uji skoring terlebih dahulu untuk melihat karakteristik mutu organoleptik. Penilaian untuk uji skoring dapat dilihat pada Tabel 1. Kemudian dilanjutkan dengan uji kesukaan atau uji hedonis. Uji kesukaan dilakukan untuk melihat penerimaan panelis terhadapa karakteristik mutu organoleptik bubuk kakao. Panelis dapat memberikan angka berupa nilai pada tingkat skala hedonik dengan rentang 1-5, dengan 1 untuk tidak suka, 2 untuk kurang suka, 3 untuk cukup suka, 4 untuk suka dan 5 untuk sangat suka. 
Tabel 1. Uji sensoris organoleptik bubuk kakao menggunakan uji skoring

\begin{tabular}{|c|c|c|}
\hline $\begin{array}{c}\text { Parameter } \\
\text { Sensoris }\end{array}$ & Skor & Deskripsi \\
\hline \multirow{5}{*}{ Aroma } & 5 & Sangat kuat aroma coklat \\
\hline & 4 & Kuat aroma coklat \\
\hline & 3 & cukup kuat \\
\hline & 2 & kurang kuat aroma coklat \\
\hline & 1 & Tidak kuat/tidak ada aroma coklat \\
\hline \multirow{5}{*}{ Rasa } & 5 & Sangat pahit \\
\hline & 4 & Pahit \\
\hline & 3 & Cukup pahit \\
\hline & 2 & Kurang pahit \\
\hline & 1 & Tidak pahit \\
\hline \multirow{5}{*}{ Warna } & 5 & Coklat gelap \\
\hline & 4 & Coklat agak gelap \\
\hline & 3 & Coklat \\
\hline & 2 & Cokelat agak muda \\
\hline & 1 & Cokelat muda \\
\hline \multirow{5}{*}{ Keasaman } & 5 & Sangat asam \\
\hline & 4 & asam \\
\hline & 3 & cukup asam \\
\hline & 2 & kurang asam \\
\hline & 1 & tidak asam \\
\hline
\end{tabular}

\section{Rancangan Penelitian}

Faktor yang diteliti meliputi pengaruh suhu dan lama pengepresan terhadap tingkat penerimaan panelis bubuk kakao. Rancangan penelitian menggunakan pola rancangan acak lengkap (RAL) dengan dua faktor, yaitu suhu dan lama pengepresan. Data hasil analisis sensoris selanjutnya dianalisis secara statistik menggunakan metode Analysis of Variance (ANOVA) dengan uji Kriskall Wallis, jika terdapat perbedaan maka dilanjutkan dengan uji beda nyata menggunakan Mann Whitney U Test pada taraf signifikansi $\alpha=5 \%$. (Referensi 5 dan 7 atau 4)

\section{HASIL DAN PEMBAHASAN}

Uji sensori dilakukan untuk mengetahui karakteristik mutu dalam suatu produk pangan, salah satunya dengan cara uji skoring dan uji kesukaan. Dalam penelitian ini parameter yang diuji meliputi warna, aroma, rasa, dan keasaman sebagai aspek penilaian mutu sensori bubuk kakao. Pertama, dilakukan uji skoring untuk melihat karakteristik mutu bubuk kakao, kemudian dilakukan uji kesukaan untuk melihat penerimaan panelis terhadap karakteristik mutu bubuk kakao.

\section{Uji Skoring}

Pengujian ini dilakukan dengan cara mendeskripsikan karakteristik mutu produk dalam bentuk skala atau skor. Rentang skala atau skoring yang digunakan antara 1-5, dengan penjelasan seperti pada tabel 1. Hasil penilaian panelis terhadap karakteristik mutu bubuk kakao dapat dilihat pada tabel 2 . (Referensi 7 Caraka) Hasil penelitian menunjukkan bahwa waktu dan lama 
pengepresan berpengaruh terhadap rasa, tidak mempengaruhi aroma. warna dan keasaman bubuk kakao, namun

Tabel 2. Hasil penilaian panelis terhadap bubuk kakao hasil pengepresan dengan beberapa variasi suhu dan lama pengepresan

\begin{tabular}{|c|c|c|c|c|c|c|}
\hline \multirow{2}{*}{ Perlakuan } & \multicolumn{2}{|c|}{ Variabel Independen } & \multicolumn{4}{|c|}{ Parameter } \\
\cline { 2 - 7 } & $\begin{array}{c}\text { Waktu } \\
(\mathbf{m i n})\end{array}$ & $\begin{array}{c}\text { Suhu } \\
(\mathbf{C})\end{array}$ & Aroma & Rasa & Warna & Keasaman \\
\hline $\mathrm{A}$ & 30 & 70 & 3,27 & $2,69 \mathrm{a}$ & $2,35 \mathrm{ab}$ & $2 \mathrm{a}$ \\
\hline $\mathrm{B}$ & 30 & 100 & 2,85 & $2,53 \mathrm{a}$ & $2,15 \mathrm{~b}$ & $1,81 \mathrm{a}$ \\
\hline $\mathrm{C}$ & 30 & 110 & 2,69 & $2,81 \mathrm{a}$ & $2,42 \mathrm{ab}$ & $1,96 \mathrm{a}$ \\
\hline $\mathrm{D}$ & 45 & 70 & 2,88 & $2,81 \mathrm{a}$ & $2,85 \mathrm{a}$ & $2,38 \mathrm{ab}$ \\
\hline $\mathrm{E}$ & 45 & 100 & 2,92 & $3,15 \mathrm{ab}$ & $3,08 \mathrm{c}$ & $2,12 \mathrm{ab}$ \\
\hline $\mathrm{F}$ & 45 & 110 & 3,04 & $2,88 \mathrm{a}$ & $3,58 \mathrm{~d}$ & $2,31 \mathrm{ab}$ \\
\hline $\mathrm{G}$ & 20 & 70 & 3,12 & $3,54 \mathrm{~b}$ & $2,65 \mathrm{a}$ & $2,62 \mathrm{~b}$ \\
\hline $\mathrm{H}$ & 20 & 100 & 3,38 & $3,08 \mathrm{ab}$ & $2,73 \mathrm{a}$ & $2,46 \mathrm{ab}$ \\
\hline $\mathrm{I}$ & 20 & 110 & 3,38 & $3,08 \mathrm{ab}$ & $2,73 \mathrm{a}$ & $2,46 \mathrm{~b}$ \\
\hline
\end{tabular}

\section{Aroma}

Aroma merupakan bau yang muncul saat makanan masuk ke dalam mulut, sehingga memberikan rangsangan kimia yang tercium oleh syaraf pada rongga hidung. Aroma dapat mempengaruhi cita rasa dan kelezatan bahan pangan (Winarno, 2004). Pada tabel 2 kita bisa melihat hasil penilaian panelis terhadap aroma bubuk kakao hasil pengepresan dengan berbagai variasi waktu dan suhu. Dari seluruh sampel, perlakuan dengan suhu 100 dan 110 selama 20 menit mendapat penilaian paling tinggi, yaitu sebesar 3,38 yang berarti cukup kuat aroma cokelatnya. Sedangkan penilaian paling rendah diperoleh sampel dengan perlakuan suhu 110 selama 30 menit yaitu sebesar 2,69. Namun dari hasil statistik menunjukkan bahwa suhu dan lama pengepresan tidak berpengaruh signifikan terhadap aroma bubuk kakao $(\mathrm{P}>0,05)$. Dengan kata lain, aroma bubuk kakao tidak dipengaruhi oleh proses pengepresan.

Menurut Misnawi dkk, (2006), meningkatnya $\mathrm{pH}$ pasta dapat mendorong pembentukan senyawa-senyawa aroma khas cokelat. Selain itu, aroma coklat muncul pada saat proses penyangraian melalui reaksi Mailard (Haryadi dan Supriyanto, 2012). Pratiwi (2016) melakukan induced maillard reaction untuk mengetahui perubahan kualitas citarasa dan aroma kakao. Diperoleh hasil analisis profil komponen aroma berupa enam senyawa volatile yaitu asam karboksilat, ester, aldehida, keton, pirazin dan fenol.

\section{Rasa}

Rasa dapat dideskripsikan sebagai karakteristik sensori yang muncul dari indera pengecap saat makanan masuk ke dalam mulut dan dikonsumsi (Meilgaard et al, 1999). Pada umumnya terdapat empat rasa dasar yang dikenali oleh manusia yaitu asin, asam, manis dan pahit (Soekarto, 2012). Rasa yang dimaksud pada uji skoring ini adalah rasa pahit dari bubuk kakao. Pada tabel 2 kita bisa melihat hasil penilaian panelis terhadap rasa bubuk kakao hasil pengepresan dengan berbagai variasi waktu dan suhu. Dari seluruh sampel, perlakuan dengan suhu 70 selama 20 menit mendapat penilaian paling tinggi, yaitu sebesar 3,54 yang berarti pahit. Sedangkan penilaian paling rendah diperoleh sampel dengan perlakuan suhu 100 selama 30 menit yaitu 
sebesar 2,53. Dari hasil statistik menunjukkan bahwa suhu dan lama pengepresan berpengaruh signifikan terhadap rasa bubuk kakao $(\mathrm{P}<0,05)$. Dengan kata lain, rasa bubuk kakao dipengaruhi oleh proses pengepresan.

Rasa pahit merupakan salah satu atribut mutu yang khas dan alami dari produk coklat. Rasa pahit dipengaruhi oleh komponen alkaloid seperti theobromin dan caffeine, komponen fenolic, pirazin, beberapa peptide, dan asam amino bebas (Ramlah, 2016).

\section{Warna}

Warna merupakan penentu awal mutu bahan pangan. Suatu produk pangan yang memiliki rasa dan aroma yang baik tidak akan dikonsumsi jika memiliki warna yang kurang enak dilihat (Winarno, 2004). Pada tabel 2 kita bisa melihat hasil penilaian panelis terhadap warna bubuk kakao hasil pengepresan dengan berbagai variasi waktu dan suhu. Dari seluruh sampel, perlakuan dengan suhu 110 selama 45 menit mendapat penilaian paling tinggi, yaitu sebesar 3,48 yang berarti berwarna cokelat. Sedangkan penilaian paling rendah diperoleh sampel dengan perlakuan suhu 100 selama 30 menit yaitu sebesar 2,15. Dari hasil statistik menunjukkan bahwa suhu dan lama pengepresan berpengaruh signifikan terhadap warna bubuk kakao $(\mathrm{P}<0,05)$. Dengan kata lain, warna bubuk kakao dipengaruhi oleh proses pengepresan.

Salah satu yang mempengaruhi warna coklat adalah suhu. Panas yang diberikan dapat menyebabkan terjadinya penurunan kadar air yang cepat. Pada kadar air yang rendah dapat mengakibatkan reaksi pencoklatan tidak berlangsung dengan

\section{Uji Kesukaan}

Uji kesukaan atau uji hedonik merupakan pengujian yang paling banyak digunakan untuk mengukur tingkat kesukaan terhadap produki. Tingkat kesukaan ini menggunakan skala hedonik, sempurna karena mobilitas antar reaktan sangat terbatas. Selain itu, kenaikan suhu yang cepat dapat menyebabkan terjadinya pirolisis yang dapat menyebabkan kerusakan struktur jaringan hingga menjadi hangus (Supriyanto dan Marseno, 2010).

\section{Keasaman}

Keasaman biji kakao memiliki peranan penting dalam menentukan citarasa produk coklat. Keasaman yang identik dengan nilai $\mathrm{pH}$ memiliki peranan penting dalam reaksi Maillard. Peningkatan $\mathrm{pH}$ pasta dapat memicu pembentukan senyawa-senyawa aroma khas cokelat (Misnawi, dkk., 2006). Tigkat keasaman sangat mempengaruhi citarasa dan aroma produk cokelat. Semakin tinggi tingkat keasaman, akan menghasilkan potensi aroma yang lebih tinggi jika dibandingkan dengan keasaman $(\mathrm{pH})$ yang rendah (Atmaja, dkk., 2016). Pada tabel 2 kita bisa melihat hasil penilaian panelis terhadap keasaman bubuk kakao hasil pengepresan dengan berbagai variasi waktu dan suhu. Keasaman bubuk kakao hasil penilaian panelis memiliki skor 1,8 2,6 yang berarti bubuk kakao kurang asam atau bisa dikatakan cukup asam. Dari seluruh sampel, perlakuan dengan suhu 70 selama 20 menit mendapat penilaian paling tinggi, yaitu sebesar 2,62 yang berarti cukup asam. Sedangkan penilaian paling rendah diperoleh sampel dengan perlakuan suhu 100 selama 30 menit yaitu sebesar 1,81. Dari hasil statistik menunjukkan bahwa suhu dan lama pengepresan berpengaruh signifikan terhadap keasaman bubuk kakao $(\mathrm{P}<0,05)$. Dengan kata lain, keasaman bubuk kakao dipengaruhi oleh proses pengepresan.

yaitu 1 untuk tidak suka, 2 untuk kurang suka, 3 untuk cukup suka, 4 untuk suka dan 5 untuk sangat suka. Hasil penerimaan atau kesukaan panelis terhadap karakteristik mutu bubuk kakao dapat dilihat pada tabel 2 . 
Tabel 3. Hasil penerimaan panelis terhadap bubuk kakao hasil pengepresan dengan beberapa variasi suhu dan lama pengepresan

\begin{tabular}{|c|c|c|c|c|c|c|}
\hline \multirow{2}{*}{ Perlakuan } & \multicolumn{2}{|c|}{ Variabel Independen } & \multicolumn{4}{|c|}{ Parameter } \\
\cline { 2 - 7 } & $\begin{array}{c}\text { Waktu } \\
(\mathbf{m i n})\end{array}$ & $\begin{array}{c}\text { Suhu } \\
(\mathbf{C})\end{array}$ & Aroma & Rasa & Warna & Keasaman \\
\hline A & 30 & 70 & $3,38 \mathrm{a}$ & 2,50 & 2,81 & 2,77 \\
\hline B & 30 & 100 & $2,81 \mathrm{~b}$ & 2,23 & 2,81 & 2,65 \\
\hline C & 30 & 110 & $2,77 \mathrm{~b}$ & 2,42 & 2,92 & 2,58 \\
\hline D & 45 & 70 & $3,04 \mathrm{ab}$ & 2,08 & 2,69 & 2,54 \\
\hline E & 45 & 100 & $2,54 \mathrm{~b}$ & 2,50 & 2,85 & 2,69 \\
\hline F & 45 & 110 & $2,65 \mathrm{~b}$ & 2,62 & 2,85 & 2,92 \\
\hline G & 20 & 70 & $3,04 \mathrm{ab}$ & 2,58 & 2,96 & 2,62 \\
\hline H & 20 & 100 & $3,58 \mathrm{a}$ & 2,65 & 3,12 & 2,73 \\
\hline I & 20 & 110 & $3,08 \mathrm{ab}$ & 2,88 & 2,54 & 2,81 \\
\hline
\end{tabular}

\section{Aroma}

Hasil sidik ragam menunjukkan bahwa suhu dan lama pengepresan berpengaruh signifikan terhadap kesukaan panelis pada aroma bubuk kakao. Hasil uji hedonis pada tabel 3 memperlihatkan bahwa aroma bubuk kakao hasil pengepresan dengan suhu 70 selama 30 menit memperoleh nilai paling tinggi yaitu sebesar 3,38 yang berarti cukup disukai oleh panelis. Rerata aroma semua perlakuan dapat dikategorikan cukup suka meskipun secara statistik nilai yang diperoleh dianggap berbeda nyata. Hal ini sejalan dengan uji skoring dimana mutu organoleptik bubuk kakao untuk aroma diperoleh hasil cukup kuat.

\section{Rasa}

Hasil sidik ragam menunjukkan bahwa suhu dan lama pengepresan tidak berpengaruh signifikan $(\mathrm{P}>0,05)$ terhadap kesukaan panelis pada rasa bubuk kakao. Hasil uji hedonis pada tabel 3 memperlihatkan bahwa rasa bubuk kakao hasil pengepresan dengan suhu 110 selama 20 menit memperoleh nilai paling tinggi yaitu sebesar 2,88 yang berarti cukup disukai oleh panelis. Rerata rasa untuk semua perlakuan dapat dikategorikan kurang suka. Kemungkinan besar penyebabnya adalah sebagian besar masyarakat Indonesia kurang suka dengan coklat pahit. Hal ini sejalan dengan hasil penelitian yang dilakukan oleh Hadi dan Siratunnisak (2016) terkait pembuatan minuman bekatul dengan tambahan bubuk coklat, bahwa minuman bekatul dengan tambahan bubuk coklat paling tidak disukai oleh panelis dari segi rasa, disebabkan karena minuman instan bekatul cenderung pahit meski sudah diberi gula.

\section{Warna}

Hasil sidik ragam menunjukkan bahwa suhu dan lama pengepresan tidak berpengaruh signifikan $(\mathrm{P}>0,05)$ terhadap kesukaan panelis pada warna bubuk kakao. Hasil uji hedonis pada tabel 3 memperlihatkan bahwa warna bubuk kakao hasil pengepresan dengan suhu 100 selama 20 menit memperoleh nilai paling tinggi yaitu sebesar 3,12 yang berarti cukup disukai oleh panelis. Rerata warna untuk semua perlakuan dapat dikategorikan cukup suka. Kemungkinan besar penyebabnya adalah sebagian besar masyarakat Indonesia kurang suka dengan coklat pahit. Hal ini sejalan dengan hasil uji skoring yang mana diperoleh rerata warna cokelat. Menurut Misnawi (2006), warna produk coklat dipengaruhi oleh kehalusan partikel. Semakin padat produk 
coklat akan memberikan keuntungan warna secara visual lebih menarik dan tidak cepat pudar.

\section{Keasaman}

Hasil sidik ragam menunjukkan bahwa suhu dan lama pengepresan tidak berpengaruh signifikan $(\mathrm{P}>0,05)$ terhadap kesukaan panelis pada keasaman bubuk kakao. Hasil uji hedonis pada tabel 3 memperlihatkan bahwa keasaman bubuk kakao hasil pengepresan dengan suhu 110

\section{KESIMPULAN DAN SARAN}

Suhu dan lama pengepresan mempengaruhi rasa, warna dan keasaman bubuk kakao pada uji skoring. Sedangkan untuk uji kesukaan, suhu dan lama pengepresan hanya berpengaruh pada aroma bubuk kakao. Aroma bubuk kakao hasil pengepresan dengan seluruh perlakuan cukup kuat dan cukup disukai. Rasa bubuk kakao hasil pengepresan selama 45 menit memperoleh nilai paling tinggi yaitu sebesar 2,92 yang berarti cukup disukai oleh panelis. Rerata keasaman untuk semua perlakuan dapat dikategorikan cukup suka. Jika disesuaikan dengan hasil uji skoring, hal ini menujukkan bahwa panelis cukup menyukasi bubuk kakao yang kurang asam. Karena menurut Jinap dan Zeslinda (1995), keasaman yang terlalu tinggi akan memberikan rasa asam pada produk coklat yang tidak disukai.

dengan seluruh perlakuan pahit dan kurang disukai. Warna bubuk kakao hasil pengepresan dengan seluruh perlakuan cokelat dan cukup disukai. Keasaman bubuk kakao hasil pengepresan dengan seluruh perlakuan kurang asam dan cukup disukai.

\section{DAFTAR PUSTAKA}

Abdul Hadi \& Nadia Siratunnisak. 2016. Pengaruh Penambahan Bubuk Coklat terhadap Sifat Fisik, Kimia, dan Organoleptik Minuman Instan Bekatul. Jurnal AcTion, 1 (2), 121129.

Adeyeye, E.I., R.O. Akinyeye, I. Ogunlade, O. Olaofe, J.O. Boluwade. 2010. Effect of farm and industrial processing on the amino acid profile of cocoa beans. Food Chemistry $118,357-363$.

Atmaja, I. P. M., Haryadi, \& Supriyanto. 2016. Peningkatan Kualitas Biji Kakao Non Fermentasi Melalui Perlakuan Pendahuluan Sebelum Inkubasi. Jurnal Tanaman Industri dan Penyegar. 3 (1); 11-20.

Chatib, O. C., Sandra, \& Asbani, H. M. (2015). Study of Equipment Presses of Cocoa Powder (Theobroma cacao, L) to Produce Quality Fat Cocoa and Analysis of the Resulting. International Journal on Advanced Science Engineernig Information Technology, 5 (6), 510-517

Erniati, Zakaria, F. R., dan Priosoeryanto, B. P. 2012. Efek Konsumsi Minuman Bubuk Kakao (Theobroma cacao L.) Bebas Lemak terhadap Sifat Antioksidatif Limfosit Subyek Perempuan. Jurnal Teknologi dan Industri pangan, 23 (1), 81-85.

Haryadi \& Supriyanto. 2012. Teknologi Cokelat. Gadjah Mada University Press. Yogyakarta Indarti E. (2007). Efek Pemanasan terhadap Rendemen Lemak pada Proses Pengepresan Biji Kakao. Jurnal Rekayasa Kimi dan Lingkungan, 6 (2), 50-54.

Jinap, S. \& A. Zeslinda (1995). Influence of organic acids on flavour perception of Malaysian dan Ghanian cocoa beans. Journal of Food Science dan Technology, 32, 153-155. 
Jinap, S., W.I. Wan Rosli, A.R. Russly, \& L.M. Nurdin. 1998. Effect of roasting time and temperature on volatile components profile during nib roasting of cocoa beans (Theobroma cacao). Journal of the Science and Food Agriculture, 77, 441-448.

Junaidi, L., Sudibyo, A., Hutajulu, T. F., \& Abdurakhman, D. (2008). Pengaruh Perlakuan Suhu Ekstraksi terhadap Karakteristik Mutu Lemak Kakao. Journal of Agro-based Industry, 25 (2), 24-34.

Meilgaard M, GV Civille \& BT Carr. 1999. Sensory Evaluation Techniques New York: CRC Press.

Mulato, S., Widyotomo, S., \& Nuraini, H. (2004). Kinerja Alat Penghalus Pasta Cokelat Tipe Silinder Berputar. Pelita Perkebunan, 20, 37-53.

Nazaruddin, R., H. Osman, S. Mamot, S. Wahid \& N. Aini. 2006. Influence of roasting conditions and volatile plavor of roasted Malaysian cocoa beans. J. Of Food Process. And Preserv. 30, p.280-298.

Pratiwi, R. 2016. Pencoklatan Non-Enzimatis Maillard Terinduksi (IMR) sebagai Upaya Peningkatan Kualitas Citarasa dan Aroma Kakao Rakyat (Skripsi). Jurusan Teknologi Hasil Pertanian. Universitas Jember. http://repository.unej.ac.id/bitstream/handle/123456789/77805/Radhiyyan\%20Pratiwi\% 20-\%20111710101016.pdf?sequence=1 (10 Oktober 2018)

Ramlah, S. 2016. Karakteristik Mutu dan Citarasa Cokelat Kaya Polifenol. Jurnal Industri Hasil Perkebunan, 11 (1): 23-32.

Rocha, I. S., Santana, L. R. R., Soares, S. E., \& Bispo, E, S. 2017. Effect of the roasting temperature and time of cocoa beans on the sensory characteristics and acceptability of chocolate. Food Sci. Technol, Campinas, 37(4): 522-530.

Setiawan, Agung. 2007. Penentuan Kondisi Pengempaan Lemak Kakao (Cocoa Butter) secara Mekanik. Skripsi. FTP. IPB. Bogor

Soekarto ST. 2012. Penelitian organoleptik untuk industri pangan dan hasil pertanian. Liberty. Yogyakarta

Supriyanto, dan Marseno, D. W. 2010. Penyangraian Hancuran Nib Kakao dengan Enerji Gelombang Mikro untuk Menghasilkan Cokelat Bubuk. Agritech, 30 (4), 243-249.

Wahyudi, T. 1988. Periksa kakao dan komponenkomponennya. Pelita Perkebunan 4 (3): 106110.

Winarno, F.G. 2004. Kimia Pangan dan Gizi. PT. Gramedia Pustaka Utama. Jakarta.

Y. Li et al. 2012. The effect of alkalization on the bioactive and flavor related components in commercial cocoa powder. Journal of Food Composition and Analysis. 25, 17-23. 